\title{
Disturbed Glucocorticoid Receptor Autoregulation and Corticotropin Response to Dexamethasone in Depressives Pretreated With Metyrapone
}

\author{
Rainer Rupprecht, Johannes Kornhuber, Noriert Wodarz, \\ Johannes Lugauer, Claudia Göbel, Doris Haack, Georg Beck, \\ Otto-Albrecht Müller, Peter Riederer, and Helmut Beckmann
}

We studied glucocorticoid receptor autoregulation and corticotropin response to dexamethasone in depressed patients and controls, attempting to control for the confounding effect of endogenous glucocorticoids. After depletion of endogenous cortisol, depressed patients showed an attenuated suppressibility of corticotropin by dexamethasone in the face of unchanged dexamethasone plasma levels. $\beta$-endorphin levels were strongly correlated with adrenocorticotropic hormone (ACTH) concentrations. Although metyrapone administration resulted in a marked rise of glucocorticoid receptor sites per cell in controls, this effect was not present in depressives. These data support the hypothesis of a decreased glucocorticoid receptor plasticity and a partial steroid resistance in depression.

\section{Introduction}

Abnormalities of hypothalamic-pituitary-adrenal (HPA) system integrity linked to depression include 24-hr hypersecretion of cortisol during depressive episodes (Linkowski et al 1985, 1987), inadequate suppressibility of cortisol by dexamethasone (Carroll et al 1968), and hyperresponsiveness of the adrenal cortex to exogenous corticotropin [adrenocorticopic hormone (ACTH)] (Amsterdam et al 1984). Moreover, hypersecretion of corticotropin-releasing hormone (CRH) has been detected in the cerebrospinal fluid of depressed patients (Nemeroff et al 1984). Studies on the application of ovine (Gold et al 1984, 1986) and human (Holsboer et al 1984a, 1987; Rupprecht et al 1989a) CRH in depression have shown an attenuated response of ACTH in depressed patients, possibly related to hypercortisolemia (Gold et al 1986). However, recent investigations were unable to reproduce the blunted ACTH response to $\mathrm{CRH}$ in depression, when cortisol synthesis was previously blocked with the 11- $\beta$-hydroxylase inhibitor metyrapone (MET) (von

From the Department of Psychiatry, University of Würzburg (RR, JK, NW, JL, CG, PR, HB), the Department of Psychiatry, University of Erlangen (GB), the Department of Pharmacology, University of Heidelberg (DH), and the Department of Internal Medicine, University of Munich (O-AM), Germany.

Address reprint requests to Dr. R. Ruppre:ht, Max-Planck-Institute for Psychiatry, Kraepelinstrasse 10, 8000 München 40, Germany.

Received July 24, 1990; revised November 14, 1990. 
Bardeleben et al 1988; Lisansky et al 1989). Instead, even an augmented ACTH response to CRH has been noted in depressives after equalizing the amount of the glucocorticoidmediated feedback in all subjects (Lisansky et al 1989).

An escape of plasma ACTH (Fang et al 1981) and $\beta$-endorphin (Matthews et al 1986, Rupprecht et al 1988) from dexamethasone suppression in endogenously depressed patients provided evidence of a subtle derangement of the feedback regulation of the HPA system during depression. Moreover, reports of an inadequate suppression of prolactin (Meltzer et al 1982; Klein et al 1984; Rupprecht et al 1987) and thyroid-stimulating hormone (TSH) (Rupprecht et al 1989c) as well as an augmented reponse of the hypothalamic-pituitary-somatotropic (HPS) system (Rupprecht et al 1989b) following glucocorticoid administration in depression have supported the idea that the derangement of the glucocorticoid-mediated negative feedback is not only restricted to the HPA system but involves a variety of neuroendocrine systems. In addition, dexamethasone bioavailability has been shown to be lower in depressed patients witis : positive dexamethasone suppression test (DST) (Holsboer et al 1984b; Lowy and Meltzer 1987; Holsboer et al 1986), resulting in a shortened dexamethasone half-life in DST nonsuppressors due to an enhanced elimination of the test drug (Holsboer et al 1986).

Several authors have investigated the potential role of glucocorticoid receptors (GR) in this context, with considerably different results. Some reports noted lower GR sites per cell in depressed patients (Gormley et al 1985; Whalley et al 1986), whereas others found a reduced downregulation of GR concentrations only in DST nonsuppressors (Lowy et al 1988) or failed to detect differences between depressed patients and controls or between DST nonsuppressors and suppressors (Schlechte and Sherman 1985).

Hypercortisolemia in depression represents a major confounding factor in accurate assessment of the HPA system and its feedback mechanism. The present study, designed to determine the effect of dexamethasone (DEX) administered in vivo on ACTH and $\beta$ endorphin levels in relation to DEX plasma concentrations and GR autoregulaticn, avoided the potential effects of hypercortisolemia by metyrapone (MET)-induced blockage of cortisol synthesis.

\section{Subjects and Methods}

\section{Subjects}

The patient group comprised 5 men and 13 women with unipolar major depressive disorder or bipolar depression aged between 18 and 72 years (mean $\pm S D, 50.0 \pm 15.1$ years), with a mean ( \pm SD) body weight of $73.8 \pm 13.7 \mathrm{~kg}$. The control group comprised 2 men and 12 women aged between 33 and 57 years (mean $\pm S D, 47.1 \pm 7.2$ years), with a mean ( \pm SD) body weight of $68.4 \pm 10.1 \mathrm{~kg}$. All subjects were carefully screened for prevalence of medical illness that might influence pituitary-adrenal function by medical history, physical examination, and routine laboratory tests. Six female depressives and five female controls were tested during the midluteal phase of the cycle; the other women were postmenopausal. DSM-III-R (American Psychiatric Association 1987) diagnoses were made on all patients by the consensus of two psychiatrists, who were blind to laboratory results. Severity of depression was assessed by the 21-item Hamilton Rating Scale for Depression (HRSD) (Hamilton 1960). The mean ( \pm SD) HRSD score of the patients was $27.2 \pm 4.6$, ranging from 18 to 36 . Patients were studied after a drug-free period of at least $72 \mathrm{hr}$. Details on clinical and demographic data of the patients and the medication given before the drug-free interval are shown in Table 1. 
Table 1. Demographic Data, Antidepressants Prior to the Washout Period, and Diagnostic Description of the Depressed Patients

\begin{tabular}{|c|c|c|c|c|c|c|}
\hline $\begin{array}{l}\text { Patient } \\
\text { no. }\end{array}$ & $\begin{array}{c}\text { Age } \\
(y r) / s e x\end{array}$ & DSM-III-R & HRS-D & $\begin{array}{l}\text { Drug-free } \\
\text { period } \\
\text { (d) }\end{array}$ & $\begin{array}{l}\text { Treatment before } \\
\text { drug-free period }\end{array}$ & $\begin{array}{l}\text { Depressive } \\
\text { episodes }\end{array}$ \\
\hline 1 & $44 / F$ & Bipolar disorder, depressed & 33 & $>\mathbf{2 8}$ & & 3 \\
\hline 2 & $66 / F$ & MDD, recurrent, with melancholia & 36 & $>28$ & & 2 \\
\hline 3 & $61 / F$ & $\begin{array}{l}\text { MDD, recurrent, with melancholia, } \\
\text { mood congruent psychotic }\end{array}$ & 28 & $>28$ & & 3 \\
\hline 4 & 64/F & MDD, recurrent, with melancholia & 28 & $>28$ & & 4 \\
\hline 5 & 39/F & MDD, recurrent & 25 & 7 & Amitryptiline 100 mg & 3 \\
\hline 6 & 60/M & MDD, recurrent, with melancholia & 24 & 5 & Amitryptiline 100 mg & 3 \\
\hline 7 & 60/M & MDD, recurrent, with melancholia & 28 & 5 & Maprotiline $150 \mathrm{mg}$ & 3 \\
\hline 8 & $34 / F$ & MDD, recurrent, with melanchoiia & 28 & 4 & Maprotiline $100 \mathrm{mg}$ & 3 \\
\hline 9 & 49/M & MDD, single episode & 21 & 7 & Maprotiline $100 \mathrm{mg}$ & 1 \\
\hline 10 & 31/F & Bipolar disorder, depressed & 18 & 4 & Lorazepam 3 mg & 1 \\
\hline 11 & $55 / \mathbf{F}$ & MDD, recurrelit, with melancholia & 26 & 5 & Maprotiline 150 mg & 2 \\
\hline 12 & 26/F & $\begin{array}{l}\text { MDD, single episode with } \\
\text { melancholia }\end{array}$ & 26 & 4 & Amitryptiline 75 mg & 1 \\
\hline 13 & 60/M & Bipolar disorder, depressed & 30 & 6 & Clomipramine $150 \mathrm{mg}$ & 6 \\
\hline 14 & $57 / F$ & $\begin{array}{l}\text { MDD, recurrent, with melancholia, } \\
\text { mood congruent psychotic }\end{array}$ & 31 & 5 & Maprotiline 150 mg & 2 \\
\hline 15 & $72 / F$ & MDD, recurrent & 29 & 5 & Amitryptiline 150 mg & 3 \\
\hline 16 & 54/F & Bipolar disorder, depressed & 33 & $>\mathbf{2 8}$ & & 6 \\
\hline 17 & 18/F & MDD, single episode & 26 & $>28$ & & 1 \\
\hline 18 & 53/M & MDD, recurrent & 26 & $>21$ & & 2 \\
\hline
\end{tabular}

Controls had no history of psychiatric disorder and were medication free for at least 4 weeks.

\section{Study Design}

After the nature of the study had been fully explained, written informed consent was obtained from patients and controls. The test protocol was approved by the ethics committee of the University of Würzburg and the requirements of the revised version of the Helsinki Declaration were strictly followed. All subjects were admitted to a sleep laboratory unit at least $1 \mathrm{hr}$ prior to drug administration or blood sampling.

For determination of GR binding characteristics and hormone data $50 \mathrm{ml}$ blood were collected at 4 PM into prechilled plastic tubes containing EDTA on three consecutive days. On day 1 , baseline values were obtained. On day 2 , the subjects were pretreated with $1.5 \mathrm{~g} \mathrm{MET}$ at $9 \mathrm{AM}$ administered orally with milk to avoid severe gastric symptoms. One milligram DEX was given orally at $11 \mathrm{PM}$. On day 3, administration of $1.5 \mathrm{~g} \mathrm{MET}$ was given as described for day 2 . The study design is summarized in Table 2. Eighty percent of the subjects experienced a transient dizziness and a hot flush after MET administration, which disappeared spontaneously within 45-60 min.

\section{Assays}

Glucocorticoid Receptor Assay. GR pharmacological characteristics were determined as described in detail elsewhere (Rupprecht et al 1990). A mononuclear cell fraction was prepared by sodium metrizoate-Ficoll density gradient centrifugation (Boyum 1968). Cells 
Table 2. Description of the Study Design in Schematic Form

\begin{tabular}{clllll}
\hline \multicolumn{1}{c}{ Day 1 } & \multicolumn{2}{c}{ Day 2 } & \multicolumn{2}{c}{ Day 3 } \\
\hline Blood sampling & MET & Blood sampling & DEX & MET & Blood sampling \\
& $(1.5 \mathrm{~g})$ & & $(1 \mathrm{mg})$ & $(1.5 \mathrm{~g})$ & \\
$4 \mathrm{PM}$ & $9 \mathrm{AM}$ & $4 \mathrm{PM}$ & $11 \mathrm{PM}$ & $9 \mathrm{AM}$ & $4 \mathrm{PM}$ \\
\hline
\end{tabular}

were washed two times in phosphate-buffered saline (PBS) for $10 \mathrm{~min}$, incubated for 60 min at $37^{\circ} \mathrm{C}$ to allow sufficient dissociation of endogenous hormone, and hen washed again. The final concentration of cells was determined using a Coulter Counter (Model S5, Coulter Electronics Ltd, England). Viability of cells exceeded 95\%, as judged from their ability to exclude trypan blue. Contamination by erythrocytes was less than $10 \%$, and contamination by granulocytes and monocytes was less than $8 \%$ and did not differ among the three test days or between patients and controls.

Binding experiments were carried out at $37^{\circ} \mathrm{C}$ in plastic microtiter plates in a total volume of $0.25 \mathrm{ml}$ using $10^{6}$ cells per well. The displacing compound (final concentration $10 \mu \mathrm{mol} / \mathrm{L}$ unlabeled dexamethasone) was added immediately prior to the addition of $\left[{ }^{3} \mathrm{H}\right]$ dexamethasone (specific activity $84 \mathrm{Ci} / \mathrm{mmol}$ ) to determine nonspecific binding. Saturation experiments were performed on each blood sample using increasing concentrations of $\left[{ }^{3} \mathrm{H}\right]$ dexamethasone from 1 to $40 \mathrm{nmol} / \mathrm{L}$. Saturation experiments were performed at equilibrium after a 90-min incubation period. After incubation, bound ligand was separated from free ligand by rapid filtration through Scatron filters with a Titertek cell harvester (Scatron, England) by washing with PBS (pH = 7.4) at room temperature. The filters were transferred into plastic vials, $5 \mathrm{ml}$ of a toluene-based scintillation cocktail was added, and they were monitored for tritium in a Beckman LS 1801 counter at about 54\% efficiency. All samples were assayed in triplicate with a variation within a single experiment of less than $7 \%$. The interassay variability was $7 \%$.

Hormone Assays. ACTH was measured by an IRMA supplied by the Nichols Institute (San Juan Capistrano, CA), which does not require extraction procedures (Raff and Findling 1989). A soluble sandwich complex is formed by a ${ }^{125}$ I-labeled monoclonal antibody directed against $\mathrm{N}$-terminal ACTH and a biotin-coupled polyclonal antibody against C-terminal ACTH. The sandwich compleres are bound by adding avidin-coated plastic bead. Inbound components are washed away and the radioactivity bound to the solid phase is monitored in a gamma counter. The lower detection limit was $1.5 \mathrm{pmol} / \mathrm{L}$, and the intraassay and interassay coefficients of variation were $3 \%$ and $6.8 \%$, respectively. Values below the detection limit were recorded as $1.5 \mathrm{pmol} / \mathrm{L}$.

$\beta$-Endorphin was determinied by radioimmunoassay (RIA) (ImmunoNuclear Corp, Stillwater, MN) after extraction with anti- $\beta$-endorphin antibodies coupled to Sepharose (Rupprecht et al 1988, 1989a). The minimal detectable concentration was $1.5 \mathrm{pmol} / \mathrm{L}$, and the intraassay and interassay coefficients of variation were $6 \%$ and $8 \%$, respectively.

Cortisol was measured by a direct RIA (Stalla et al 1981). The lower detection limit was $25 \mathrm{nmol} / \mathrm{L}$, and the intraassay and interassay coefficients of variation were $5 \%$ and 9\%, respectively. As there was a cross-reactivity of our cortisol antibody with 11-deoxycortisol of about $15 \%$, determinations of cortisol values following MET administration would not be accurate and were excluded from further analysis.

11-Deoxycortisol (11-DOC) was determined by a radioimmunologic method described 
$\log 11-\mathrm{DOC}$ [nmol/L]

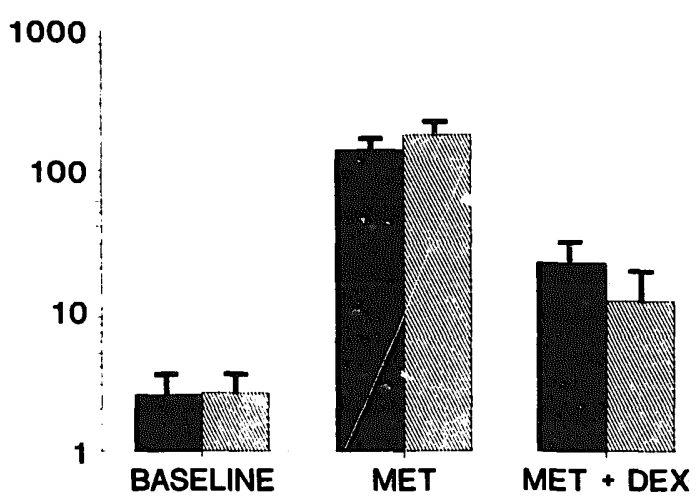

Figure 1. Mean \pm SE 11-deoxycortisol (11DOC) concentrations in depressed patients (solid bars, $n=18$ ) and normal controls (shaded bars, $n=14$ ).

previously (Vecsei 1981). 11-DOC was extracted from plasma using ethylglycole and assayed directly using an antibody raised against the C-3-oxime of the steroid. The lower detection limit was $1.5 \mathrm{nmol} / \mathrm{L}$. The recovery was about $80 \%$, and the intraassay and interassay coefficients of variation were $5 \%$ and $13 \%$, respectively. Cross-reactivities were $1.5 \%$ with cortisol and $0.2 \%$ with DEX. DEX was measured in unprocessed plasma using a direct RIA method with antibodies raised against the C-3-oxime of DEX as described in detail elsewhere (Haack et al 1981).

The lower detection limit was $0.5 \mathrm{nmol} / \mathrm{L}$. The intraassay and interassay variations were $6.7 \%$ and $14.7 \%$, respectively.

\section{Data Analysis}

Preliminary estimates of binding parameters from saturation experiments were provided by the EBDA program (McPershon 1983). Final estimates of binding parameters were determined with a computerized nonlinear, least-square regression analysis (Munson and Rodbard 1980). This weighted curve fitting program assumes binding according to the law of mass action to independent classes of binding sites. The results are expressed as the mean $\pm S D$, and as the mean \pm SE in Figures 1-5.

Differences in receptor and hormone data within subjects were analyzed by analysis of variance (ANOVA) for repeated measurements. Differences between patients and controls and between depressive subgroups were analyzed by ANOVA followed by post hoc comparisons with Student's $t$-test. Additionally, the ANOVA was repeated with the cofactors age, HRSD score, and cortisol, ACTH, 11-DOC, and DEX concentrations. Contingency tables were analyzed by $\chi^{2}$ analysis with Yates correction. Correlation data were obtained by Pec.son's product moment correlation. All significance levels are twotailed.

\section{Results}

Administration of MET resulted in a sufficient blockade of the 11- $\beta$-hydroxylase, as shown by the excessive rise in 11-DOC (Figure 1) $(p<0.001)$, ACTH (Figure 2$)(p<$ $0.001)$, and $\beta$-endorphin (Figure 3) $(p<0.001)$ in patients and controls, which was avoided by DEX pretreatment. Baseline cortisol values at $4 \mathrm{PM}$ did not differ significantly 


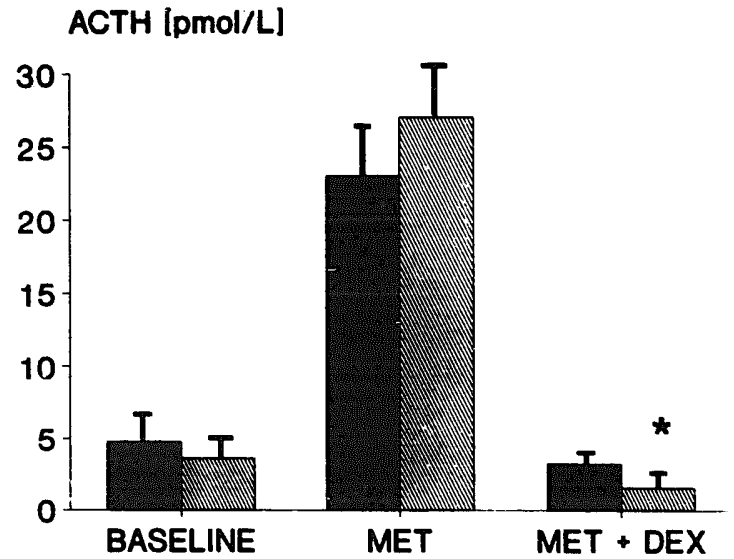

Figure 2. Mean \pm SE ACTH concentrations in depressed patients (solid bars, $n$ $=18$ ) and normal controls (shaded bars, $n=14)$. The asterisk indicates a significant difference $(p<0.05)$.

between patients (mean $\pm \mathrm{SD}, 253.1 \pm 115.7 \mathrm{nmol} / \mathrm{L}$ ) and controls (mean $\pm \mathrm{SD}, 218.0$ $\pm 74.5 \mathrm{nmol} / \mathrm{L}$ ). Although 11-DOC concentrations did not differ between patients and controls under either test condition, depressed patients exhibited slightly higher ACTH concentrations after MET + DEX pretreatment $(p<0.05)$ (Figure 2). The corresponding $\beta$-endorphin values just failed to reach statistical significance $(p<0.07)$. ACTH and $\beta$ endorphin values were strongly correlated in the patient and control group as well as in both groups combined $(r=0.8, p<0.001)$. Dexamethasone plasma levels were similar in depressives (mean $\pm \mathrm{SD}, 2.72 \pm 0.25 \mathrm{nmol} / \mathrm{L})$ and controls $(2.47 \pm 0.22 \mathrm{nmol} / \mathrm{L})$.

Of the 14 controls, 13 showed complete suppression of ACTH below the detection limit of the assay of $15 \mathrm{pmol} / \mathrm{L}$ following DEX administration ("ACTH suppressors"). In contrast, only 8 of 18 patients were able to suppress ACTH completely, whereas the remaining 10 patients had postdexamethasone ACTH levels ranging from 2.6 to 8.6 pmol/L ("ACTH nonsuppressors"). $\chi^{2}$ analysis with Yates correction indicated a significantly greater proportion of "ACTH nonsuppressors" among the patients $(p<0.02)$. Surprisingly, there was no difference in DEX plasma concentrations between ACTH nonsuppressors (mean $\pm \mathrm{SD}, 2.32 \pm 0.87 \mathrm{nmol} / \mathrm{L}$ ) and suppressors (mean $\pm \mathrm{SD}, 2.74$ $\pm 0.90 \mathrm{nmol} / \mathrm{L}$ ), while baseline cortisol values were significantly higher in ACTH non-

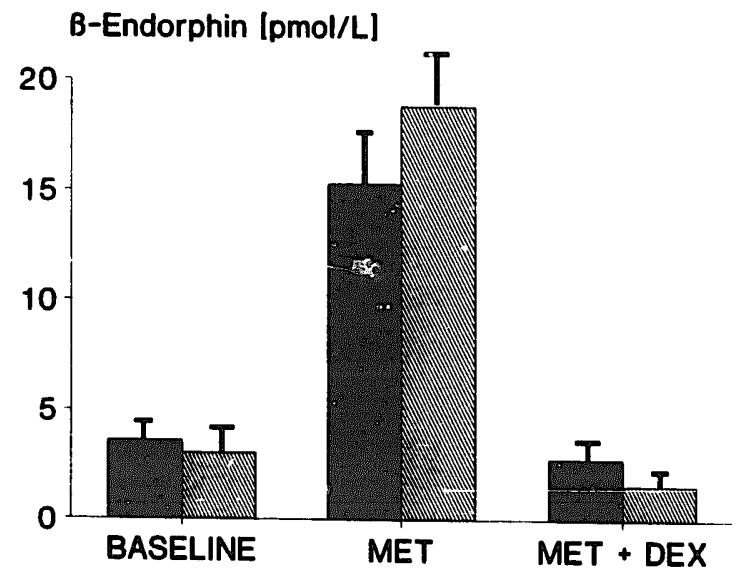

Figure 3. Mean $\pm S E \beta$-endorphin concentrations in depressed patients (solid bars, $n=18$ ) and normal controls (shaded bars, $n=14)$. 


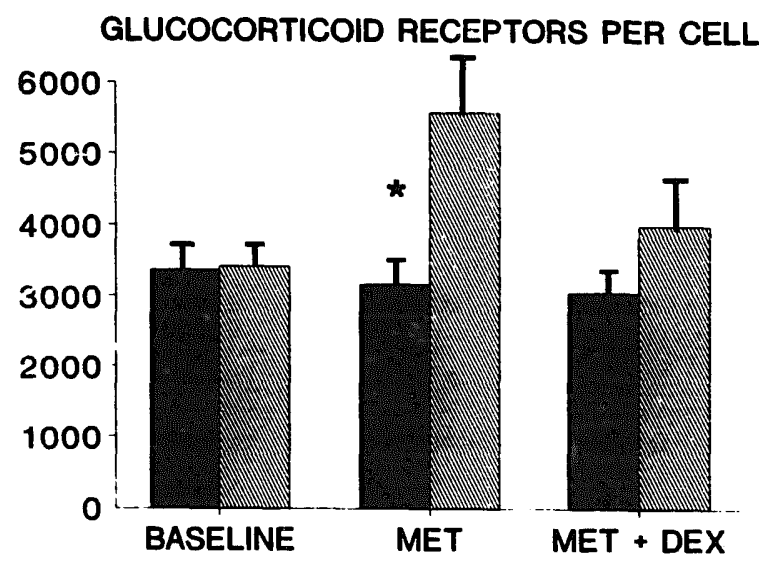

Figure 4. Mean \pm SE glucocorticoid receptor sites per cell in depressed patients (solid bars, $n=15$ ) and normal controls (shaded bars, $n=18$ ). The asterisk indicates a significant difference $(p<0.005)$.

suppressors (mean $\pm \mathrm{SD}, 294.8 \pm 124.8$ versus $206.5 \pm 72.4 \mathrm{nmol} / \mathrm{L})(p<0.05)$. There was no relationship among age, sex, HRSD score, depressive subtype, number of depressive episodes, length of previous episode, length of the washout period, or treatment prior to the washout period and cortisol, ACTH, or $\beta$-endorphin concentration.

To determine the effects of baseline cortisol levels and ACTH, 11-DOC, and DEX plasma concentrations on GR binding characteristics in relation to diagnostic group as main effect, these factors were included as covariates in the ANOVA model for diagnostic group. With these covariates entered to allow for their maximum contribution, depressed patients had significantly fewer GR sites per cell $(p<0.005)$ (Figure 4$)$ and a lower $K_{d}$ $(p<0.04)$ (Figure 5) following MET administration when compared with controls. The covariates did not contribute significantly to the explanation of the variance. No significant difference could be observed with regard to baseline and MET + DEX pretreated test conditions. There was an inverse relationship between baseline cortisol and baseline GR sites per cell in the whole sample $(r=-0.63, p<0.001)$ and in the patient group ( $r$ $=-0.72 ; p<0.01)$ but not within the control group $(r=0.51, \mathrm{NS})$. GR binding parameters did not correlate with ACTH, $\beta$-endorphin, 11-DOC, or DEX concentrations under either test condition. Moreover, the clinical features mentioned above showed no

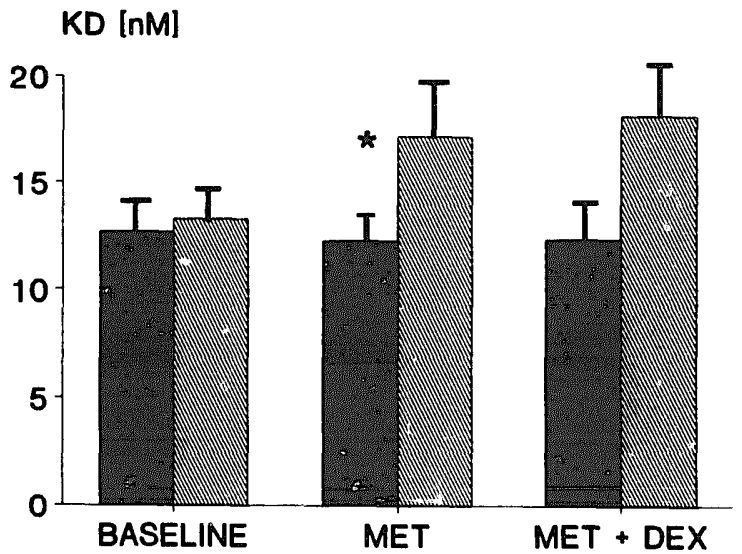

Figure 5. Mean \pm SE $K_{d}$ in depressed patients (solid bars, $n=18$ ) and normal controls (shaded bars, $n=14$ ). The asterisk indicates a significant difference ( $p$ $<0.04)$. 
association with GR paradigms. There were no differences between patients drug free for more than 21 days, and those with a shorter washout period with regard to hormone or GR data.

\section{Discussion}

Although a variety of studies (Arana et al 1985) have replicated the frequently occurring attenuated response of cortisol to DEX in patients with major depressive disorder, the pathophysiology of DST nonsuppression remains still unsolved. It has been suggested that the positive DST reflects hypercortisolemia (Poland et al 1987), and studies on DEX pharmacokinetics have shown a decreased bioavailability in depressed DST nonsuppressors (Lowy and Meltzer 1987; Holsboer et al 1986) due to a shortened half-life of the test drug (Holsboer et al 1986). Thus, the metabolism of DEX may contribute to positive DST results. However, even if DEX plasma levels were covaried out, the degree of DST nonsuppression in depression would not be fully explained by DEX bioavailability (Poland et al 1987).

The endocrine effects of cortisol and DEX are mediated via the mineralocorticoid receptor (MR) (type I) in the hippocampus and preferentially via the GR (type Ii) in the hippocampus, the hypothalamus, and the pituitary (Arriza et al 1987; De Kloet and Reul 1987). We therefore investigated whether the response of the HPA system to DEX as a reflection of GR function in vivo is still attenuated in depressed patients after eliminating by MET the competition of DEX with elevated endogenous cortisol in relation to DEX plasma concentrations. Although we did not find a significant elevation of 4 PM baseline cortisol, this does not exclude hypercortisolemia, since it was only a single point measurement and the HPA axis is relatively quiescent at this time (Amsterdam et al 1987). Further studies should apply a multiple time point measurement to detect eventual shifts in the rhythm of ACTH or cortisol. There was an attenuated response of ACTH to DEX in depressives, with a significantly greater proportion of patients than controls with incomplete suppression of ACTH by DEX. These data show that the impaired response of ACTH and $\beta$-endorphin in endogenous depression previously described under baseline conditions (Fang et al 1981; Matthews et al 1986; Rupprecht et al 1988) still persists after depletion of endogenous cortisol. The attenuated response of ACTH to DEX independent of hypercortisolemia and DEX bioavailability in depression lends support to the idea of a defect of GR function in vivo, as has been suggested by reports of an impaired response also of prolactin (Meltzer et al 1982; Rupprecht et al 1987) and TSH (Rupprechi et al 1989c) to DEX in depression.

Our study of baseline GR binding characteristics did not reveal any difference between depressed patients and controls or between ACTH nonsuppressors and suppressors. These findings confirm previous investigations (Schlechte and Sherman 198.) and suggest that the GR is not downregulated by hypercortisolemia in depression. However, other groups have reported lower GR sites in depression (Gormley et al 1985; Whalley et al 1986). Although GR has been reported to be under autoregulatory control in animals (Reul et al 1987) and humans (Rupprecht et al 1990), the patients showed no changes of GR binding characteristics related to major shifts of glucocorticoid levels whereas the controls responded to depletion of endogenous cortisol with a marked rise in GR sites per cell. Thus, the inverse relation of GR sites and cortisol levels in depressives but not in controls reflects steroid resistance rather than GR downregulation. This is further supported by the absence of clinical features of a Cushing's syndrome despite the remarkable hyper- 
cortisolemia noted in some of the depressive patients (Gormley et al 1985). The decrease in GR affinity (increase in $K_{d}$ ) in controls probably reflects a competition of the METinduced excess in 11-DOC with labeled DEX because high amounts of 11-DOC can also bind to GRs (De Kloet and Reul 1987) without affecting the estimation of GR sites per cell (Rupprecht et al 1990). The lack of this effect in depressives also points to steroid resistance.

However, GR binding data did not correlate with the effect of DEX on ACTH secretion. It is important in this context that the response of the HPA system to DEX is mediated via GR sites in the hippocampus, the hypothalamus, and the pituitary. The hippocampal GR has been shown to underlie a more sensitive autoregulation than other brain regions (McEwen et al 1987). Although recent investigations showed a certain parallelism in the response to reserpine of the GR in the hippocampus and in leukocytes of rats (Lowy 1990), the extrapolation from the measurement of peripheral GR regulation to central nervous GR regulation should only be made with caution.

Hypercortisolemia in depression represents a major confounding factor in the assessment of the HPA system and in neurotransmitter studies by action via the GR, since immunocytochemical procedures with monoclonal antibodies (Fuxe et al 1985) have shown GRs to be present in almost all brain regions, with relatively high concentrations in the hippocampus and the hypothalamus. After this effect is controlled for by depletion of endogenous cortisol with MET, our data suggest a decrease in GR plasticity with a partial steroid resistance in vitro and in vivo in depressive patients. Monoclonal antibodies (Fuxe et al 1985) and cDNA (Okret et al 1986; Dong et al 1988) or cRNA (Kalinyak et al 1989) probes are promising tools for further elucidating the deficiency of the GR and the derangement of the HPA system in depression.

\section{References}

American Psychiatric Association, Committee on Nomenclature and Statistics. Diagnostic and Statistical Manual of Mental Disorders, 3rd ed rev. Washington, DC: American Psychiatric Press, 1987.

Amsterdam JD, Winokur A, Abelmann E, Lucki I, Rickels K (1984): Cosyntropin (ACTH ${ }_{1-24}$ ) stimulation test in depressed patients and healthy subjects. Am J Psychiatry 140:907-909.

Amsterdam JD, Maislin G, Winokur A, Kling M, Gold P (1987): Pituitary and adrenocortical reponses to the ovine corticotropin-releasing hormone in depressed patients and healthy volunteers. Arch Gen Psychiatry 44:775-781.

Arana GW, Baldessarini RJ, Ornsteen M (1985): The dexamethasone suppression test for diagnosis and prognosis in psychiatry. Commentary and review. Arch Gen Psychiatry 42:1193-1204.

Arriza JL, Weinberger C, Cerelli G, et al (1987): Cloning of human mineralocorticoid receptor complementary DNA: Structural and functional kinship with the glucocorticoid receptor. Science 237:268-275.

Boyum A (1968): Separation of leukocytes from blood and bone marrow. Scand J Clin Lab Invest 21:97-107.

Carroll BJ, Martin FI, Davis BM (1968): Resistance to suppression by dexamethasone of plasma 11-OHCS levels in se ere depressive illness. $\mathrm{Br}$ Med $J$ 3:285-287.

De Kloet ER, Reul JMHM (1987): Feedback action and tonic influence of corticosteroids on brain function: A concept arising from the heterogeneity of brain receptor systems. Psychoneuroendocrinology 12:83-105.

Dong Y, Poellinger L, Gustafsson JA, Okret S (1988): Regulation of glucocorticoid receptor expression: Evidence for transcriptional and posttranslational mechanisms. Mol Endocrinol 2:1256-1264. 
Fang VS, Tricou BJ, Robertson A, Meltzer HY (1981): Plasma ACTH and cortisol levels in depressed patients: Relation to the dexamethasone suppression test. Life Sci 29:931-938.

Fuxe K, Wikström AC, Okret S, et al (1985): Mapping of glucocorticoid receptor immunoreactive neurons in the rat tel- and diencephalon using a monoclonal antibody against the rat liver glucocorticoid receptor. Endocrinology 117:1803-1812.

Gold PW, Chrousos GP, Kellner C, et al (1984): Psychiatric implications of basic and clinical studies with corticotropin releasing factor. Am J Psychiatry 141:619-627.

Gold PW, Loriaux DL, Roy A, et al (1986): Responses to corticotropin-releasing hormone in the hypercortisolism of depression and Cushing's disease. N Engl J Med 314:1329-1335.

Gormley GJ, Lowy MT, Reder AT, et al (1985): Glucocorticoid receptors in depression: Relationship to the dexamethasone suppression test. Am J Psychiatry 142:1278-1284.

Haack D, Günther D, Kunkel G, Lichtwald K, Täuber U, Vecsei P (1981): Radioimmunologische Bestimmung von synthetischen Glucocorticoiden. Atemw-Lungenkrkh 7:283-289.

Hamilton M (1960): A rating scale for depression. J Neurol Neurosurg Psychiatry 23:56-62.

Holsboer F, Bardeleben U, Gerken A, Stalla GK, Müller OA (1984a): Blunted corticotropin response and normal cortisol responses to human corticotropin-releasing fartor in depression. N Engl J Med 311:1127.

Holsboer F, Haack D, Gerken A, Vecsei P (1984b): Plasma dexamethasone concentrations and differential glucocorticoid suppression response in depressives and controls. Biol Psychiatry 19:281-290.

Holsboer F, Wiedemann K, Boll E (1986): Shortened dexamethasone half-life in depressed nonsuppressors. Arch Gen Psychiatry 43:813-815.

Holsboer F, Gerken A, Stalla GK, Müller OA (1987): Blunted aldosterone and ACTH release after human CRH administration in depressed patients. Am J Psychiatry 144:229-231.

Kalinyak JE, Griffin CA, Hamilton RW, Bradshaw JG, Perlman AJ, Hoffman AR (1989): Developmental and hormonal regulation of glucocorticoid receptor messenger RNA in the rat. $J$ Clin Invest 84:1843-1848.

Klein HE, Seibold B, Bender W, Nedopil N, f.lbus M, Schmauss M (1984): Postdexamethasone prolactin and cortisol: A biological state variable in depression. Acta Psychiatr Scand 70:239_ 247.

Linkowski P, Mendlewicz J, Leclercq R, et al (1985): The 24-hour profile of adrenocorticotropin and cortisol in major depressive illness. $J$ Clin Endocrinol Metab 61:429-438.

Linkowski P, Medlewicz J, Kerkhofs M, et al (1987): 24-hour profiles of adrenocorticotropin, cortisol, and growth hormone in major depressive illness: Effect of antidepressant treatment. $J$ Clin Endocrinol Metab 65:141-152.

Lisansky J, Peake GT, Strassman RI, et al (1989): Augmented pituitary corticotropin response to a threshold dosage of human corticotropin-releasing hormone in depressives pretreated with metyrapone. Arch Gen Psychiatry 46:641-649.

Lowy MT (1990): Reserpine-induced decrease in type I and II corticosteroid receptors in neuronal and lymphoid tissues of adrenalectomized rats. Neuroendocrinology 51:190-196.

Lowy MT, Meltzer HY (1987): Dexamethasone bioavailability: Implications for DST research. Biol Psychiatry 22:373-385.

Lowy MT, Reder AT, Gormley GJ, Meltzer HY (1988): Comparison of in vivo and in vitro glucocorticoid sensitivity in depression: Relationship to the dexamethasone suppression test. Biol Psychiatry 24:619-530.

Matthews J, Akil H, Greden J, et al (1986): $\beta$-Endorphin/ $\beta$-lipotropin immunoreactivity in endogenous depression. Arch Gen Psychiatry 43:374-381.

MicEwen B, Chao H, Spencer R, Brinton R, Macisaac L, Harrelson A (1987): Corticosteroid 
receptors in brain: Relationship of recepturs to effects in stre ss and aging. Ann NY Acad Sci 512:394-401.

McPershon GA (1983): A practical computer-based approach to the analysis of radioligand binding experiments. Comput Programs Biomed 17:107-114.

Meltzer HY, Fang VS, Tricou BJ, Robertson A, Piyaka SK (1982): Effect of dexamethasone on plasma prolactin and cortisol levels in psychiatric patients. Am J Psychiatry 139:763-769.

Munson PJ, Rodbard D (1980): LIGAND: A versatile computerized approach for characterization of ligand-binding systems. Anal Biochem 107:220-239.

Nemeroff JB, Widerlöv E, Bisette G, et al (1984): Elevated concentrations of CSF corticotropinreleasing factor-like immunoreactivity in depressed patients. Scier. 'e 226:1342-1343.

Okret S, Poellinger L, Dong Y, Gustafsson JA (1986): Downregulation of glucocorticoid receptor mRNA by glucocorticoid hormones and recognition by the receptor of a specific sequence within a receptor cDNA clone. Proc Natl Acad Sci USA 83:5899-5903.

Poland RE, Rubin RT, Lesser IM, Lane LA, Hart PJ (1987): Neuroendocrine aspects of primary endogenous depression: II. Serum dexamethasone concentrations and the hypothalamic-pituitary-adrenal cortical activity as determinants of the dexamethasone suppression test response. Arch Gen Psychiatry 44:790-795.

Raff H, Findling JW (1989): A new immunoradiometric assay for corticotropin evaluated in normal subjects and in patients with Cushing's syndrome. Clin Chem 35:596-600.

Reul JMHM, van den Bosch FR, de Kloet ER (1987): Differential response of type I and type II corticosteroid receptors to changes in plasma steroid level and circadian rhythmicity. Neuroendocrinology 45:407-412.

Rupprecht R, Bärocka A, Jecht E, Noder M, Pichl J, Schwarz W (1987): Prolactin response to dexamethasone: A study on normal controls and depressed patients. Acta Psychiatr Scand 76:139-143.

Rupprecht R, Barocka A, Beck G, Schrell U, Pichl J (1988): Pre-and postdexamethasone plasma ACTH and $\beta$-endorphin levels in endogenous and non-endogenous depression. Biol Psychiatry 23:531-535.

Rupprecht R, Lesch KP, Müller U, Beck G, Beckmann H, Schrlte HM (1989a): Blunted ACTH but normal $\beta$-endorphin release following human corticotropin releasing hormone (CRH) administration in depression. J Clin Endocrinol Metab 69:600-603.

Rupprecht R, Rupprecht C, Rupprecht M, Noder M, Lesch K-P, Mössner J (1989b): Effects of glucocorticoids on the regulation of the hypothalamic-pituitary-somatotropic system in depression. J Affective Disord 17:9-16.

Rupprecht R, Rupprecht C, Rupprecht M, Noder M, Mahlstedt J (1989c): Triiodothyronine, thyroxine, and TSH response to dexamethasone in depressed patients and normal controls. Biol Psychiatry 25:22-32.

Rupprecht R, Kornhuber J, Wodarz N, et al (1990): Characterization of glucocorticoid binding capacity in human mononuclear leukocytes: Increase by metyrapone is prevented by dexamethasone pretreatment. $J$ Neuroendocrinol 2:803-806.

Schlechte JA, Sherman B (1985): Lymphocyte glucocorticoid receptor binding in depressed patients with hypercortisolemia. Psychoneuroendocrinology 10:469-474.

Stalla GK, Giesemann G, Müller OA, Wood WG, Scriba PC (1981): The development of a direct homologous radioimmunoassay for serum cortisol. J Clin Chem Clin Biochem 19:427-434.

Vecsei P (1981): Glucocorticoids, cortisol, cortisone, corticosterone, compound S and their metabolites. In Jaffe BM, Behrmann HR (eds), Methods of Hormone Radioimmunoassay, 2nd ed. New York: Academic, pp 767-796.

von Bardeleben U, Stalla GK, Müller OA, Holsboer F (1988): Blunting of corticotropin response to corticotropin-releasing hormone in depressed patients is avoided by metyrapone pretreatment. Biol Psychiatry 24:782-786.

Whalley L, Borthwick N, Copolov D, Dick H, Christie JE, Fink G (1986): Glucocorticoid receptors and depression. $\mathrm{Br}$ Med J 292:859-861. 